\title{
Det sovande landet. Sibirien i rysk historia, kultur och geografi
}

\author{
Margareta Attius Sohlman \\ Stockholm: Carlsson Bokförlag 2019 \\ 255 sider. ISBN 9789173319645
}

Omtalt af Torben Heuer [lektor i russisk sprog og kultur, tidligere tilknyttet Aarhus Universitet, torben@heuer-hansen.dk]

Det sovande landet er struktureret som en række essaylignende kapitler med en vekslende og afvekslende blanding af (kultur)historiske og geografiske fakta og personlige indtryk fra åbenbart oplevelsesmættede rejser i det omhandlede område - som man måske i denne sammenhæng (ud fra bogens titel) kunne kalde "Storsibirien", eftersom det drejer sig om skiftende fokus på et kæmpemæssigt landområde, der strækker sig fra Kolahalvøen i vest til Kamtjatkahalvøen i øst.

Ifølge introduktionen til første kapitel betyder Sibirien på mongolsk altajsprog "det sovande landet" - derfra bogens hovedtitel. Men lad mig allerede i starten af min anmeldelse tilstå, at bogens gennemgang af lokaliteter efterlader denne anmelder lettere geografisk forvirret i forhold til undertitlen Sibirien i rysk historia, kultur och geografi:

Hvis man er nøjeregnende, og det vælger jeg altså at være, er det kun omkring $1 / 4$ af bogens tekstmasse (ca. 65 sider ud af 255), nemlig kapitlerne 1, 6 og 7, der faktisk behandler undertitelemnet. Af bogens samlede antal sider omhandler ca. 85 dels det russiske nord i form af Murmansk/Arkhangelsk-regionen samt Karelen i bred forstand, dels Centralasien / Silkevejen. Så referencen til »Sibirien« skal opfattes mere rummeligt end rimeligt er, forekommer det mig.

Bogen er inddelt i ni kapitler, hver med en række underrubrikker, som klart og koncist orienterer om det kaleidoskopisk opbyggede indhold: Det første kapitel "Sibirien ruvar på oändliga hemligheter« beretter blandt andet om Ruslands tidlige ekspansion østpå, om videnskabelige ekspeditioner i 1700-tallet (herunder Berings) og ultrakort om Sibirien som forvisningssted for for eksempel dekabristerne samt om tilblivelsen af Den transsibiriske jernbane. Det følgende kapitel »Europa upptäcker det medeltida Ryssland" fortæller om de tidligste besøgende i Rusland, Novgorod, kirkens rolle i 14-1500-tallet og handelskontakter med især England og Holland historisk set samt om den svenske historiograf Petrus Petrejus' rejsebeskrivelse fra starten af 1600-tallet. 
Det tredje kapitel "Vita havet och Norra ishavet" fører læseren op i tiden og giver en redegørelse for klosterliv ved Ishavet, med geografisk reference til Valamoklostrene, Kizhi, Petrozavodsk, Solovetskij-øerne og med personomtaler af blandt andre Lichatjov, Sjalamov og Lebedev i forbindelse med GULag-perioden.

De to følgende kapitler har fælles referenceramme: "Tro som trotsar tid och rum" gælder blandt andet de gammeltroende, herunder Nikon og Avvakum, samt som en slags appendiks en beretning om Anastasija - en i Canada boende gammeltroende, mens næste kapitel "Ikonernas värld" orienterer om ikonen i religiøst og idéhistorisk perspektiv, dens udvikling i Rusland, samt om ikonmalerkunsten og dens forskellige motiver.

Kapitel 6 "Från Sankt Petersburgs salar till Sibiriens gruvor" knytter an til den korte omtale af dekabristerne i kapitel 1 og byder her på en detaljeret beretning om fyrstinde Maria Volkonskajas rejse til Sibirien som "medfølgende hustru" til en af dekabrist-opstandens ledere og opholdet i blandt andet Irkutsk baseret på hendes dagbog. Dette giver anledning til at bevæge sig videre til "Bajkal - Sibiriens blå pärla", med legenden om Bajkal, Angara og Jenisej og beskrivelse af flora og fauna i Bajkal samt burjater og shamanisme, for at ende med Olchon-øen og Listvjanka-bebyggelsen.

Den sidste dels to kapitler er helliget Centralasien: "Sidenvägen - Från Samarkand till Aralsjöns skeppskyrkogård" er en introduktion til Uzbekistans historiske byer på Silkevejen og Djingis Khan, Timur Lenk, Ulug Beg, samt Aral-søen mens "Nukus - centrum för rysk avantgardekonst" fortæller om dette meget særegne ørkenmuseums historie og om udvalgte kunstnere derfra. Hertil kommer "Namnoch ortregister med uttalsanvisningar av de ryska orden" og "Litteraturförteckning".

I bogens forord er anført følgende hensigtserklæring:

De kulturer och idétraditioner som jag tar upp här hör alla med några få undantag hemma i länder i de nordliga trakterne av Europa och Asien. Min avsikt har inte varit att följa varje lands historiska eller politiska utveckling kronologiskt. Snarare har jag sökt följa olika kulturella och idéhistoriska skeenden i en slavisk, ortodox miljö för att kunna spåra en utveckling som dels skiljer sig från den västeuropeiska tradition vi känner, dels fortsättningsvis ända in i vår tid ger upphov till mellanstatliga och mellanmänskliga konflikter.

Med denne målsætning som udgangspunkt kommer læseren altså vidt omkring i både Rusland og Centralasien med Margareta Attius Sohlman som en kompetent og kyndig rejseleder, der udviser et for det meste indgående kendskab til bogens forskellige nedslagspunkter. Denne læser, som i vidt omfang har rejst i de samme områder og travet i de samme plovfurer både før og efter forfatteren, kan nikke genkendende til mangt og meget og føler sig efter endt læsning grundigt og gedigent informeret på basis af forfatterens omfattende viden om de valgte fokuspunkter, der er krydret med personlige kommentarer.

De to kapitler om henholdsvis den russisk-ortodokse tro og ikonernes verden vidner om forfatterens dybtgående kendskab til dette område og rummer mange 
velformulerede betragtninger. Jeg kan tilføje, at så vidt jeg er informeret, er de originale ikoner igen på plads i Pokrovskaja tserkov på Kizji (jf. s.75).

Jeg læste med stor fascination de to personrelaterede dagbogsberetninger, som refereres i bogen, nemlig dels Petrus Petrejus' øjenvidneskildring fra årene 16011605 i "Stora oredans tid" (Smutnoe vremja) med interessante detaljer om blandt andet den første falske Dmitrijs endeligt og Boris Godunov, dels Maria Volkonskajas Zapiski (gældende perioden 1826-1855) om fyrstindens trængsler både på færden til Sibirien til den eksilerede dekabrist-ægtemand og under opholdet i blandt andet Chita og Irkutsk, der fremmaner et portræt af en åbenbart beundringsværdig og respektindgydende kvinde og giver et underholdende indblik i hverdagslivet i den sammenhæng.

Ud over diverse oplysende faktaafsnit undervejs om blant andet historie og geografi byder bogen på en kortfattet redegørelse for miljømæssige konsekvenser af rovdriften på olie- og gasforekomster i det sibiriske område, herunder for naturen og dermed naturfolkenes levevis, såsom rensdyrdrift. Endvidere omtales - ligeledes kortfattet - klimaforandringernes alarmerende indvirkning på permafrosten. For en grundigere og mere problematiserende behandling af disse problemer skal man andre steder hen.

I kapitlet om Bajkal påpeges de negative følger af masseturismens hærgen i dette område, herunder især invasionen af kinesiske turister. For egen regning kan jeg tilføje, at russiske medier med mellemrum gør opmærksom på de problemer, som denne tilstrømningsbelastning medfører, såsom mange (undertiden ulovligt) hasteopførte nye pensionater samt en stærkt stigende affaldsmængde - et åbenbart stærkt påtrængende problem, som har fortrængt tidligere tiders nu ophørte forurening fra cellulosefabrikken i søens sydlige ende.

Jeg synes alt $i$ alt, at den foreliggende bog er en meget læseværdig og anbefalelsesværdig (kultur)historisk rejsefører. Man skal altså blot være forberedt på, at bogens indhold byder på en del andet og mere end det, som "varedeklarationen" på bogens forside lægger an til. 